Rubiliza DC. Onofre, MD

Rene Louie C. Gutierrez, MD

Department of Otorhinolaryngology

Head and Neck Surgery

East Avenue Medical Center

Diliman, Quezon Clty, Philippines
Correspondence: Rubiliza DC. Onofre, MD Department of Otolaryngology Head and Neck Surgery 6th floor East Avenue Medical Center

East Avenue, Quezon City 1100

Philippines

Phone: (632) 9280611 loc 324

Fax: (632) 4356988

E-mail:yukito8211@yahoo.com

Reprints will not be available from the author.

The authors declared that this represents original material that is not being considered for publication or has not been published or accepted for publication elsewhere, in full or in part, in print or electronic media; that the manuscript has been read and approved by all the authors, that the requirements for authorship have been met by each author, and that each author believes that the manuscript represents honest work.

Disclosures: The authors signed disclosures that there are no financial or other (including personal) relationships, intellectual passion, political or religious beliefs, and institutional affiliations that might lead to a conflict of interest.

\section{Orbital Floor Fracture Reconstruction Using Conchal Auricular Cartilage Graft}

Orbital wall fractures result from external impact injuries which cause an abrupt increase in intraorbital pressure. ${ }^{1}$ Patients usually present to the emergency room with periorbital swelling and limited eye movements, with or without changes in vision. Relatively common in the Philippines, these fractures are frequently caused by violent assault followed by vehicular accidents involving motorcycles. ${ }^{2}$ Among 119 maxillofacial trauma cases seen and treated by the Department of Otorhinolaryngology of the East Avenue Medical Center from 2008-2009, 42 were diagnosed as cases of orbital fractures with $36 \%$ having concomitant involvement of the orbital floor. Various techniques in diagnosis and treatment developed in the past 20 years, each having its own strengths and weaknesses. The challenge of choosing which among these methods will best achieve the goals of function and aesthetics always confronts surgeons particularly in a developing country setting.

We present a case of bilateral orbital floor fractures with diplopia repaired with conchal auricular cartilage graft in a 22-year-old female.

\section{CASE REPORT}

A 22-year-old female was immediately brought to our emergency room following a headon collision with an Asian utility vehicle while driving a motorcycle without a helmet. She was conscious and coherent with stable vital signs.

On examination, contusion hematomas were noted over both periorbital areas. Visual acuity was 20/30 OD and 20/40 OS with bilateral limitations of extraocular muscle movement. Bilateral ocular pressures were measured at $14.6 \mathrm{mmHg}$. Craniofacial CT Scans revealed linear frontal bone fractures with subdural hemorrhages and pneumocephalus in the frontal area, fractures of the calvarial bones, lateral orbital walls, inferior orbital rims and orbital floors (Figure 1). A mannitol drip was started for the hemorrhage.

She developed a persistent headache and binocular vertical diplopia with monocular diplopia, OS on left gaze accompanied by pain on lateral left duction. Visual acuity was 20/25 OU. On the $17^{\text {th }}$ hospital day, she underwent open reduction and internal fixation of multiple facial fractures using titanium plates and screws with reconstruction of both orbital floors using conchal cartilage autografts. The right eye diplopia resolved on the third postoperative day while the diplopia on left lateral downward gaze in the left eye resolved from the ninth postoperative day until the day of discharge.

There was complete resolution of diplopia and improvement in visual acuity to $20 / 20 \mathrm{OD}$ and $20 / 25$ OS on follow up at one year.

\section{DICUSSION}

Orbital floor fractures are relatively common midfacial injuries encountered in urban areas ${ }^{2}$ and were first described by Smith and Regan in 1957. ' Since then, many articles have been written about their diagnosis and treatment, including indications and optimal time for surgery as well as optimal surgical methods.' Epidemiological studies reveal that despite different settings, the majority of cases involve the young male population with violent assault as the most prominent etiology accounting for $37.8 \%$ of orbital blowout fractures; motor vehicle accidents came in at second with $17.6 \%$; with the remaining fractures resulting from athletics (14.1\%). ${ }^{2}$ To our 


\section{FEATURED GRAND ROUNDS}

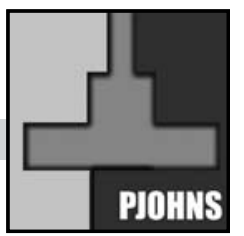

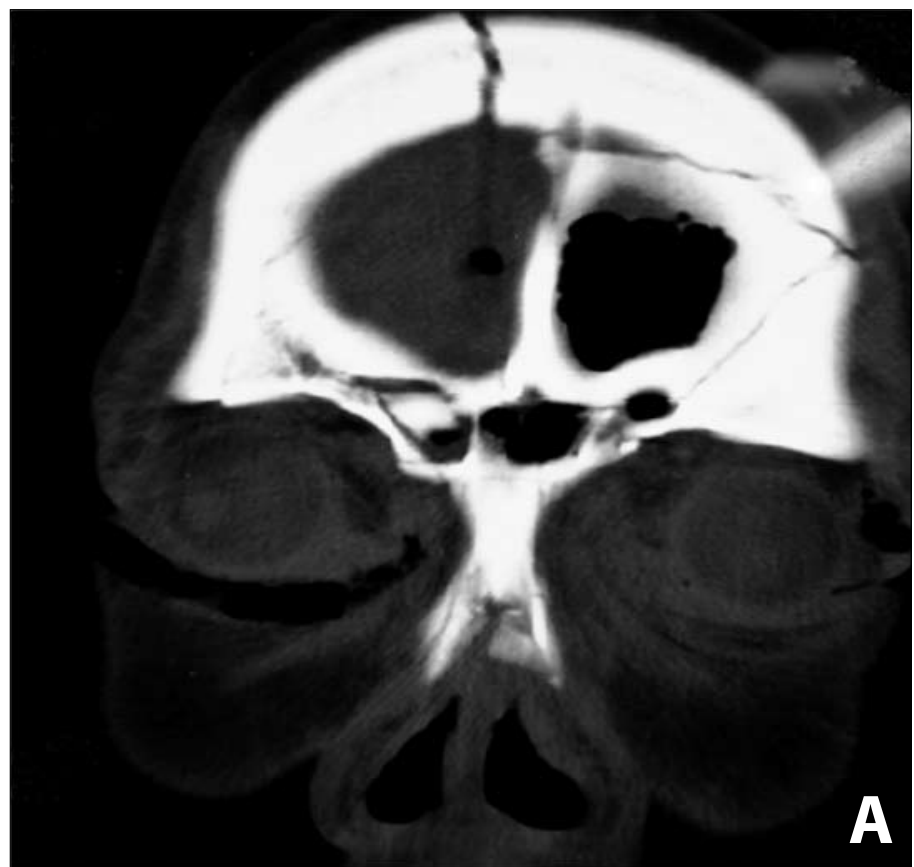

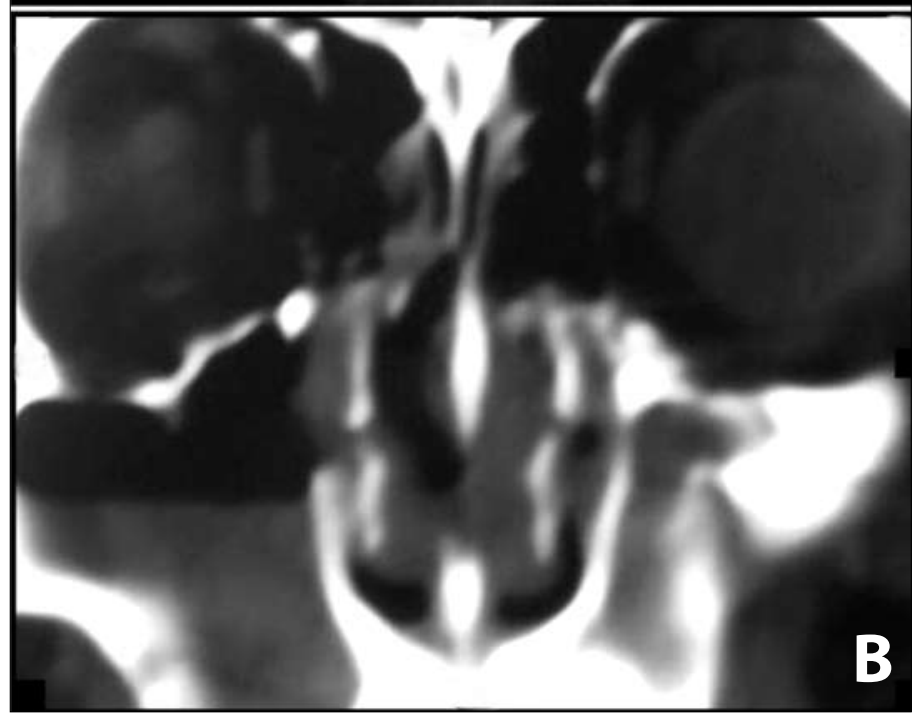

Figure 1 A and B. Craniofacial CT scan, coronal sections, revealing fractures of (A) calvarial bones and (B) inferior orbital rims and orbital floors

knowledge, local reports have not been published but similarities in profile can be deduced.

Orbital floor fractures, also known as blowout fractures, imply that the orbital rims have remained intact, whereas one or more walls of the orbit, typically the floor has fractured. ${ }^{3}$ Orbital floor fractures can be classified into pure and impure according to extent of bone involvement (Table 1). Pure blowout fractures are fractures of the floor not involving the rim while impure blowout fractures have rim extension. ${ }^{3}$ Pure orbital floor fractures are further classified as trapdoor or non-trapdoor. Trapdoor fractures are those in which either edge of the inferior orbital wall is attached to its original position, while non-trapdoor fractures are those in which the inferior orbital wall is completely separated from its original position and the periorbital tissue has prolapsed into the maxillary sinus ${ }^{1}$ (Figure 2). These fractures can be also be classified by location: anterior, posterior and anteroposterior ${ }^{1,4}$ (Figure 3). Our patient presented with non trapdoor type orbital floor fractures measuring $10 \mathrm{x}$ $4 \mathrm{~mm}$ on the right and $10 \times 5 \mathrm{~mm}$ on the left.

Patients with orbital floor fractures often complain of blurred vision and pain on eye movement. Physical examination also elicits diplopia, accompanying limitation of eye movement and enophthalmos on the affected side. These signs and symptoms are due to (1) herniation of orbital contents with concomitant partial atrophy of extraocular muscles and to (2) an increase in the volume of the orbital cavity with possible compression of the optic nerve. ${ }^{4}$ Because of these features, orbital floor fractures are classified as both Otorhinolaryngologic and Ophthalmologic emergencies that warrant immediate surgical treatment especially if the patient presents with blurred vision., ${ }^{3,5}$

Confirmatory imaging studies help locate and assess the extent of orbital floor injury. These include radiographs and computed tomography of the facial bones. The commonly used radiograph is the chin-to-nose or Water's view. This gives a view of the whole orbital area and may reveal a pathognomonic "tear drop" sign, seen as an elliptical opacity underneath the inferior orbital rim, that represents orbital contents, usually orbital fat, that herniated through the fracture., However, facial computed tomography is still the most useful imaging tool in assessing orbital floor fractures. ${ }^{1,2,3,4} \mathrm{It}$ is usually requested without contrast using 3 different cuts: coronal, axial and sagittal. Coronal cuts reveal discontinuity of the inferior orbital rims with concomitant soft tissue sublaxation; axial cuts present the extent of areas involved while sagittal cuts help locate if the fracture is anterior, posterior or anteroposterior. ${ }^{1,4}$

\section{Table 1. Comparison of Pure Versus Impure Blowout Fractures}

\begin{tabular}{|c|c|c|}
\hline \multicolumn{2}{|c|}{ Pure Blowout Fractures } & Impure Blowout Fractures \\
\hline \multicolumn{2}{|c|}{$\begin{array}{l}\text { - Fractures involving the orbital floor without extension } \\
\text { to the inferior orbital rim }\end{array}$} & \multirow{6}{*}{$\begin{array}{l}\text { - Fractures involving the orbital floor } \\
\text { with extension to the inferior orbital } \\
\text { rim }\end{array}$} \\
\hline \multicolumn{2}{|c|}{ - Can be classified as trapdoor or non-trapdoor } & \\
\hline Trapdoor fractures* $\dagger$ & Non-trapdoor fractures* $\dagger$ & \\
\hline $\begin{array}{l}\text { - One edge of the orbital } \\
\text { floor is attached to its } \\
\text { original position }\end{array}$ & $\begin{array}{l}\text { - Orbital floor completely } \\
\text { separates from its original } \\
\text { position }\end{array}$ & \\
\hline $\begin{array}{l}\text { - Periorbital contents may } \\
\text { or may not be prolapsed } \\
\text { into the maxillary sinus } \\
\end{array}$ & $\begin{array}{l}\text { - Periorbital contents prolapsed } \\
\text { into the maxillary sinus }\end{array}$ & \\
\hline $\begin{array}{l}\text { - Common among } \\
\text { anterior orbital floor } \\
\text { fractures }\end{array}$ & $\begin{array}{l}\text { - Common among posterior } \\
\text { orbital floor fractures }\end{array}$ & \\
\hline
\end{tabular}

* Kwon, JH. Kim, JG. Moon, JH. Cho, JH. Clinical analysis of surgical approaches for orbital floor fractures. Arch Facial Plast Surg. 2008 Jan-Feb;10(1):21-24

† Jin HR, Yeon JY, Shin SO, Choi YS, Lee DW. Endoscopic versus external repair of orbital blowout fractures. Otolaryngol Head Neck Surg 2007 Jan; 136(1):38-44 
The goal of surgical repair in orbital floor fractures is two-fold: to reposition herniated orbital fat and tissue back in the orbit; and to reconstruct the traumatic defect. ${ }^{4}$ Approaches are via open surgery (subciliary or transconjunctival) or endoscopic (transantral), (Table 2). The open transorbital approach is currently regarded as the mainstream method for reduction of blowout fractures of the inferior orbital wall. It is useful for releasing incarcerated soft tissue, as dissecting all soft tissue around the fracture area is necessary.' Post operative complications include ectropion and unsightly scars, but these rarely occur in the hands of experienced surgeons. ${ }^{5}$ Endoscopic repair, usually via a transantral approach, can provide surgeons with several

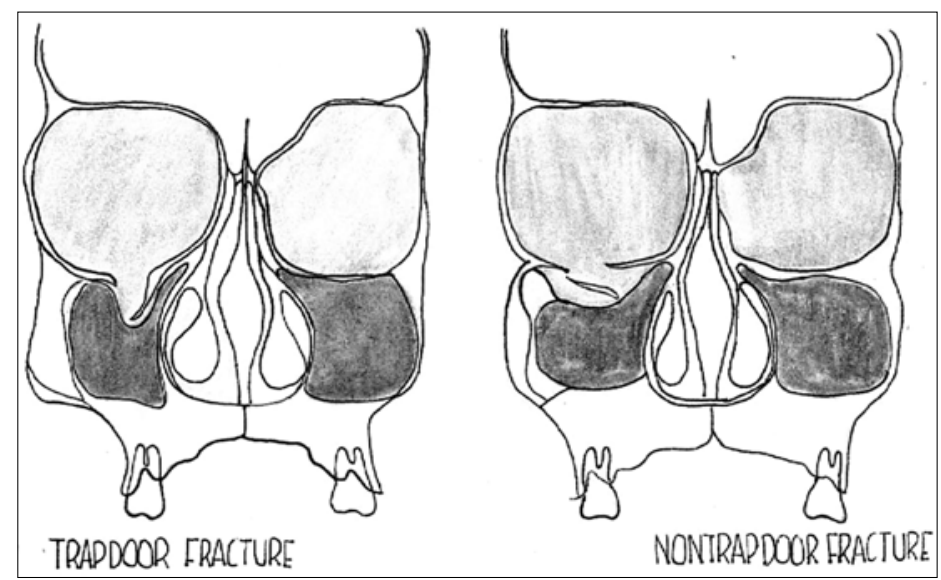

Figure 2. Illustration of fracture classification according to attachment of fragments in reference to original position; Trapdoor and nontrapdoor fracture

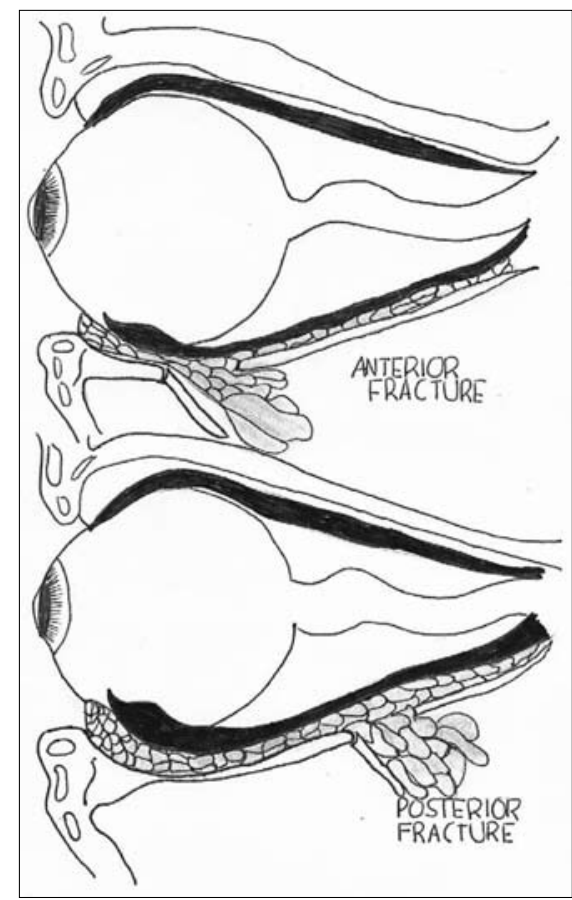

Figure 3. Illustration of fractures classified according to location; anterior and posterior fractures advantages over conventional external repair. These include excellent visualization of the medial and inferior walls of the orbit; easy access to maxillary bone (avoiding or minimizing use of intraocular alloplastic implants); virtual elimination of significantly visible facial scarring and eyelid complications; and performing the procedure under local anesthesia, making intra-operative evaluation of ocular movements and diplopia possible., $\mathrm{A}$ transorbital approach has the advantage of releasing incarcerated orbital tissue, while, in contrast, simply lifting the orbital tissue upward in a transantral approach may aggravate the incarceration' (Table 2). In this patient, the open approach was used because a mid-facial de-gloving was necessary to access other fractures.

The repair of orbital floor fractures involves many techniques, and adequate knowledge and skill is needed to perform any of these techniques employing careful judgment and analysis in formulating a plan that will fit the patient's needs. As a general principle, the orbital complex is reconstructed by aligning its fractured parts with adjacent stabilized or intact structures. ${ }^{10}$ Familiarity with the complex shape of the orbital walls is important in repair. In the case of the orbital floor, it gently concaves inferolaterally, turning convex medially to posteriorly, assuming an S-shape configuration. 1,3 The posterior part of the floor is farthest from the inferior orbital rim with the infraorbital nerve coursing thru it makes it vulnerable and weak to the extensive forces absorbed when applied into the orbital area. 1,310 This explains why posterior orbital floor fractures occur as non-trapdoor types and are difficult to expose. The orbital contents are positioned accurately and precisely into the orbit making any change in volume affect eye function. It is important to assess eye function first as it may give the examiner an idea of the extent of injury to the orbital floor. Indications for repair include diplopia, nonresolving oculocardiac reflex with entrapment (bradycardia, heartblock vomiting, nausea and syncope), fracture involving $>50 \%$ of the orbital floor, and early enophthalmos or hypoglobus causing facial asymmetry. ${ }^{11}$ These signs and symptoms elicited during physical examination with documentation of the location of fracture through diagnostic imaging warrant early repair since herniated soft orbital tissue can atrophy within 2-3 weeks post trauma. ${ }^{4}$

The types of grafts/implants used to span the defects of orbital floor fractures are divided into alloplastic and autogenous implants ${ }^{7}$ (Table 3). Autogenous grafts include bone, cartilage, and fascia. Alloplastic implants can be divided into nonabsorbable types, such as those made of silicone, polytef, hydroxyapatite, tantalum mesh, or titanium, and absorbable types, including those made of polyglactin or gel film. Repair of the orbital floor defect is mandatory if the defect measures at least $50 \%$ of the size of the orbital floor bone. The ideal implant must be nonreactive, provide good structural support, be easily positioned, and be readily available..$^{1,2,3}$ In this case the surgeon utilized conchal cartilage grafts. This graft can be used in repairing defects as large as 
FEATURED GRAND ROUNDS

\section{Table 2. Comparison Between Open Versus Endoscopic Approaches in the Repair} of Orbital Floor Fractures

\begin{tabular}{|c|c|c|}
\hline Approach & Open Surgery & Endoscopic Surgery \\
\hline Site of surgical incision & Transorbital or subcillary & Transantral \\
\hline Advantages & $\begin{array}{l}\text { - useful in releasing incarcer- } \\
\text { ated inferior orbital wall and } \\
\text { periorbital contents } \\
\text { - can provide better visualization } \\
\text { of anterior fractures } \\
\text { - ideal for anterior, trapdoor } \\
\text { orbital floor fractures* }\end{array}$ & $\begin{array}{l}\text { - provide excellent visualization of medial } \\
\text { and inferior walls of the orbit enabling } \\
\text { safe removal of bony fragments } \\
\text { - use of endoscope minimizes or eliminates } \\
\text { visible scars } \\
\text { - can be performed under local anesthesia } \\
\text { making intraoperative assessment of } \\
\text { extraocular movements and diplopia } \\
\text { possible } † \\
\text { - easy access to the maxillary bone for } \\
\text { possible graft source for reconstruction } \\
\text { minimizes use of allosteric grafts } \\
\text { - provide better exposure of the posterior } \\
\text { orbital floor fractures } \\
\text { - ideal for posterior non-trapdoor orbital } \\
\text { floor fractures }\end{array}$ \\
\hline Disadvantages & $\begin{array}{l}\text { - need for extensive dissection } \\
\text { of surrounding soft tissues for } \\
\text { proper placement of graft for } \\
\text { reconstruction } \\
\text { - difficulty in identifying and } \\
\text { exposing fractures located } \\
\text { at the posterior region of the } \\
\text { pyramidal shaped-orbit } \\
\text {-excessive dissection for good } \\
\text { exposure of posterior orbital } \\
\text { floor fractures may lead to optic } \\
\text { nerve damage } \\
\text { - can cause injury to posterior } \\
\text { orbital tissue or muscle when } \\
\text { graft place in a poorly exposed } \\
\text { and dissected area }\end{array}$ & $\begin{array}{l}\text { - use of the approach may not fully release } \\
\text { incarcerated orbital contents } \\
\text { - simply lifting of the orbital tissue upward } \\
\text { with this approach can aggravate } \\
\text { incarceration } \\
\text { - needs to be combined with transorbital } \\
\text { approach for safe implantation of graft } \\
\text { material into the inferior orbital floor }\end{array}$ \\
\hline Complications & Ectropion, visible scars & Infection, optic nerve damage * \\
\hline
\end{tabular}

* Kwon, JH. Kim, JG. Moon, JH. Cho, JH. Clinical analysis of surgical approaches for orbital floor fractures. Arch Facial Plast Surg. 2008 Jan-Feb;10(1):21-24

† Jin HR, Yeon JY, Shin SO, Choi YS, Lee DW. Endoscopic versus external repair of orbital blowout fractures. Otolaryngol Head Neck Surg 2007 Jan; 136(1):38-44

$2 \times 2 \mathrm{~mm}$. It advantages over other autogenous grafts include having a shape similar to the orbital floor, ease of harvest, malleability and limited morbidity at the donor site. ${ }^{4}$

Autogenous tissue grafts, i.e. bone or cartilage, are preferred over alloplastic grafts in the repair of isolated orbital fractures similar to this case. ${ }^{10} \mathrm{Grafts}$ (especially bone) should be secured to avoid displacement or migration and improve graft survival. Complete dissection of the fracture is necessary to identify the intact bone on all sides of the fracture since these will be used for alignment when placing the graft. In the case of an orbital floor fracture, the posterior portion of the intact

\section{Table 3. Type of Grafts Used in Recontruction of Orbital Floor Fractures}

\begin{tabular}{l|l}
\multicolumn{1}{c|}{ Autogenous Grafts } & \multicolumn{1}{c}{ Alloplastic Grafts } \\
Include bone, cartilage, and fascia & $\begin{array}{l}\text { Divided into non absorbable (silicone, polytef, } \\
\text { hydroxyapatite, tantalum mesh, or titanium) and } \\
\text { absorbable (polyglactin or gel film) }\end{array}$ \\
\hline $\begin{array}{l}\text { Advantages: } \\
\text {-readily available }\end{array}$ & $\begin{array}{l}\text { Advantages: } \\
\text {-cheap }\end{array}$ \\
\hline Disadvantages: & - do not undergo resorption \\
- easily undergo resorption except for & Disadvantages: \\
cartilage grafts & - Costly \\
- need for blood supply for nourishment & - Can cause infection \\
- increase morbidity to the patient since & - Can extrude from the surgical site \\
harvesting the graft would produce another & \\
surgical site &
\end{tabular}

bone will serve as a guide to internal orbital reconstruction. The graft should be placed in inclined position just behind the inferior orbital rim to reach the intact posterior bone. ${ }^{3,10}$ Placing the graft based on correct anatomic position during reconstruction is of more significance than using globe position as a basis in volume restoration. ${ }^{10}$ It is a must to perform duction tests following graft placement and compare these to baseline duction tests prior to surgery. ${ }^{9,10}$ This will help the surgeon distinguish if the stiff duction test is caused by edema from impingement of the musculofibrous ligament system by the graft material. ${ }^{10}$

\section{ACKNOWLEDGMENT}

The authors would like to thank Dr Natividad Almazan and Dr. Felix Nolasco for their encouragement and support; and the resident doctors of the Department of ORL-HNS for their help in making this paper.

\section{REFERENCES}

1. Kwon JH, Kim JG, Moon JH, Cho JH. Clinical analysis of surgical approaches for orbital floor fractures. Arch Facial Plast Surg. 2008 Jan-Feb;10(1):21-4.

2. Shere JL, Boole JR, Holtel MR, Amoroso PJ. An analysis of 3599 midfacial and 1141 orbital blowout fractures among 4426 United States Army Soldiers 1980-2000. Otolaryngol Head Neck Surg 2004 Feb;130(2):164-70.

3. Kellman RM. Chapter 26: Maxillofacial Trauma in Cummings CW, Flint PW, Harker LA, Haughey $\mathrm{BH}$, Richardson MA, Robbins KT, Schuller DE, Thomas, JR, eds. Cummings Otolaryngology Head and Neck Surgery, $4^{\text {th }}$ ed. Vol 4. Philadelphia (PA): Elsevier-Mosby, 2005. p. 602-36.

4. Castellani A, Negrini S, Zanetti U. Treatment of orbital floor blowout fractures with conchal auricular cartilage graft: A report on 14 cases. J Oral Maxillofac Surg. 2002 Dec; 60(12):1413-17.

5. Jin HR, Yeon JY, Shin SO, Choi YS, Lee DW. Endoscopic versus external repair of orbital blowout fractures. Otolaryngol Head Neck Surg. 2007 Jan; 136, 38-44.

6. Hinohira Y, Yumoto E, Shimamura I. Endoscopic endonasal reduction of blowout fractures of the orbital floor. Otolaryngol Head Neck Surg. 2005 Nov; 133(5): 741-7.

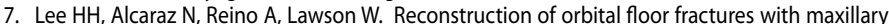
bone. Arch Otolaryngol Head Neck Surg. 1998 Jan;124(1):56-9.

8. Ducic Y, Veret DJ. Endoscopic transantral repair of orbital floor fractures. Otolaryngol Head Neck Surg. 2009 Jun;140(6):849-54.

9. Augsburger J, Asbury T. Chapter 19: Ocular and orbital trauma. Vaughan and Asbury's General Ophthalmology $16^{\text {th }}$ edition. USA: McGraw-Hill Co. Inc. 2004. p. 371-8.

10. Manson PN. Chapter 4.5 Orbital Fractures. Prein J. editor. Manual of Internal Fixation in Cranio Facial Skeleton:Techniques Recommended by AO/ASIF Maxillofacial Group. New York: SpringerVerlag 1998. p. 139-46.

11. Burnstine MA. Clinical recommendations for repair of isolated orbital floor fractures: an evidence-based analysis. Ophthalmology 2002 Jul; 109(7):1207-10. 